\title{
THE GENERAL VALUE OF GRAPHS.
}

\author{
By E. B. Hodges, \\ Clarksuille, Iowa.
}

Correlation of the various subjects in the curriculum has been discussed and various theories have been advanced only to be cast aside in actual practice. The theory discussed in the present paper seems to be a very practicable one, because first while not needing to be labeled there is actual correlation and second in connection with the correlation there is much of actual enlightenment on the subject under discussion. It is a psychological appeal to the eye.

Graphic work is a practicable theory and method of correlation. In history a graph similar to the following enables easy chronological comparison, the great men or events are seen in relation to other events and their time and relative importance designated by the line. The cost of war equipment, the relative strength of nations, in fact nearly all history can be reduced to a graph.

\begin{tabular}{|c|c|c|c|}
\hline \multicolumn{2}{|c|}{1650} & 700 & 750 \\
\hline A & & & Albany Council \\
\hline B & Bacon's rebellion & & Bunker Hill \\
\hline $\mathrm{C}$ & College of Wm, and Mary & & Columbia U. founded \\
\hline $\mathrm{D}$ & & & Declaration of Ind. \\
\hline $\mathrm{E}$ & & & \\
\hline $\mathrm{F}$ & Free Schools in Mass. & Freedom of Press & First Cont. Congress \\
\hline G & & Georgia founded & \\
\hline $\mathrm{H}$ & . & & Henry's resolutions \\
\hline
\end{tabular}

\begin{tabular}{l|l|l|l}
1800 & 1850 & \\
\hline Annex Texas & $\begin{array}{l}\text { Apponattox } \\
\text { Confederacy }\end{array}$ & \begin{tabular}{l} 
Child Labor Laws \\
\hline Dred Scott Decision
\end{tabular} \\
\hline $\begin{array}{l}\text { Florida purchase } \\
\text { Emancipation }\end{array}$ & $\begin{array}{l}\text { Fort Sumter } \\
\text { Fartford Convention }\end{array}$ & $\begin{array}{l}\text { Gadsden Purchase } \\
\text { Hague Conference }\end{array}$ \\
\hline
\end{tabular}

(Names in aiphabetical order from top to bottom for ease of reference.)

In literature a similar graph may be made showing the periods of greatest activity; and by the use of heavy or colored lines the relative importance of poetry and prose and the drama may be indicated for each period. 
In economics there are many practical applications such as the comparison of value of articles at different times, as of silver, the commercial activity of the various nations at different periods, the increase of trusts and decrease relatively of competition, and relation of imports to exports.

In civics the length of term of the different officers may be compared, the relative importance of the various courts shown, and the interlocking powers of national, state, and local governments indicated by the interlocking circles. In geography, altitudes, lengths of rivers, amount of coast lines, number of miles and relative importance of railroads, location and development of industries, amounts of rainfall, and many other items may be graphed.

In nature study the graph is very important. Before the child has started to school he has learned to outline the architecture of buildings with blocks, or, outdoors in the autumn, with leaves. In the kindergarten this tendency is still further developed. Later in the course, botany, biology, and zoölogy claim attention along this line. The study of bone structure is made more plain by the use of diagrams.

The study of the development of grammar, the origin of words, the relative number of nouns, adjectives, adverbs, and other parts of speech in one's own vocabulary may be shown. But perhaps the widest range of the graph in the school work is in mathematics. The child early learns to graph cubes and other forms and to draw straight and curved lines. Then he learns to add one line or block to another. In subtraction, multiplication, division, the solution of simultaneous and quadratic equations the direct appeal to the sense of sight by means of a picture helps to clear up the subject.

But the greatest value of the graph is the correlation with actual life. It is said that education is preparation for complete living. Is the graph used in practical life? That is where the greatest correlation occurs, school life in all its phases being correlated with actual business and professional life. Is the child to be a scientific farmer? He needs to graph the line of profits for the various departments; he needs to look at a graph of his farm to see where he can save space or make things handier. Is the child to be a business man? A graph will show the general range of prices for several years giving him a basis for estimations as to the time of year to buy, the quantity of goods to be purchased and the general market conditions. Is he to be an archi- 
tect? The designs are practically all graphs. Or an engineer? The grading, placing of underground pipes, the plans for bridges and culverts, electrical and chemical problems, the mechanism of different kinds of machinery are all graphed and must be understood. Artists, cartoonists, advertisers, publishers, carpenters, brick-masons, and practically all people can and do make use of the graph.

As graphs are of value in correlating school work, in the development and better understanding of all subjects of the curriculum, as they apply the knowledge gained in school to the problems of actual life, as it is important that they be understood in nearly all vocations, all students should have a working knowledge of the principles of graphical construction.

\section{STAND UP STRAIGHT AND GET THE FULL HORSEPOWER OUT OF YOUR HUMAN MACHINE.}

The way the human body is used is of the utmost importance if the person is to have the best of health of which the person is capable. With a person it is much the same as with the automobile. One represents a 50-horsepower engine, another a 40 , another a 30 , still another 20 , and if the body is used rightly this full amount of energy can be developed without harm. If the body is used wrongly, as is true with the machine, it may be ruined in developing half the amount of the designed horsepower. When rightly used, the parts are all in balance; there is no undue strain to any part, the chest is carried high, so that the breathing is easy, and there is the full amount of "wind power." The abdominal organs are properly supported and work with the least difficulty, the digestion and nutrition are good. . If the body is drooped or buckles in the middle, the whole body suffers, and many times disease conditions start in this way. In such drooped position the chest is flattened, so that the lungs cannot work rightly and become weak, the abdomen is telescoped and the stomach, bowels' and other organs are crowded together and work badly, so that indigestion and constipation result. Health, or the best possible efficiency, the full horsepower of the person, cannot result under such conditions any more than an engine can develop its rated horsepower if the cylinders are full of carbon, or that the fuel in the furnace can be consumed properly if the drafts are not properly open or the ashes are not removed. The position most favorable for health and in which the load or burden of life can be carried most easily is with the body, both when sitting and when standing, as it would be if a person were trying to sit or stand as tall as possible. This gives the high chest, the flat abdomen, the erect head, square shoulders, straight knees, and the springs of the whole body are set in the best way. This is the position recognized by the athletic trainers, by the singing-teachers and by all those who are expected to train individuals for great effort. The same position is best for everyone, whether the effort be great or small, or whether the work be with the head or muscle. 